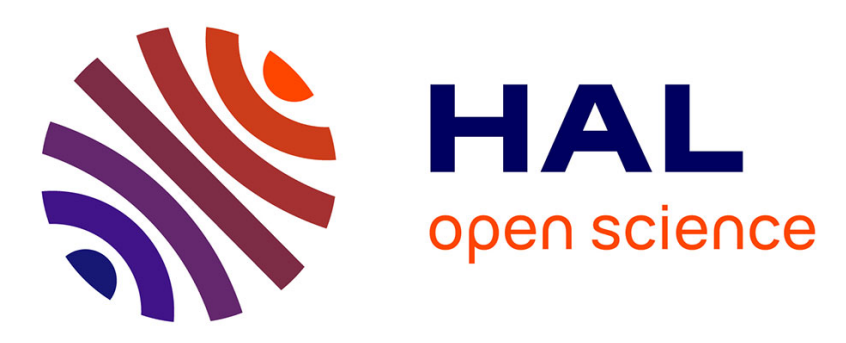

\title{
Eco-innovative Method to Improve the Distribution Phase of Product
}

\author{
Wafa Samet Kallel, Yann Ledoux, Jean-Pierre Nadeau
}

\section{To cite this version:}

Wafa Samet Kallel, Yann Ledoux, Jean-Pierre Nadeau. Eco-innovative Method to Improve the Distribution Phase of Product. International Conference on Advanced Logistics and Transport, May 2013, Sousse, Tunisia. pp.529-534, 10.1109/ICAdLT.2013.6568514 . hal-01068350

\section{HAL Id: hal-01068350 https://hal.science/hal-01068350}

Submitted on 7 May 2015

HAL is a multi-disciplinary open access archive for the deposit and dissemination of scientific research documents, whether they are published or not. The documents may come from teaching and research institutions in France or abroad, or from public or private research centers.
L'archive ouverte pluridisciplinaire HAL, est destinée au dépôt et à la diffusion de documents scientifiques de niveau recherche, publiés ou non, émanant des établissements d'enseignement et de recherche français ou étrangers, des laboratoires publics ou privés. 


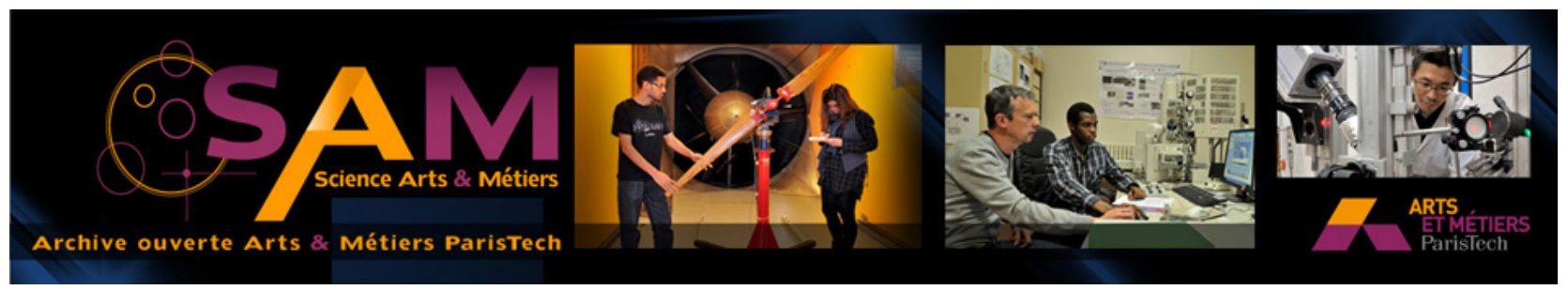

Science Arts \& Métiers (SAM)

is an open access repository that collects the work of Arts et Métiers ParisTech researchers and makes it freely available over the web where possible.

This is an author-deposited version published in: http://sam.ensam.eu Handle ID: .http://hdl.handle.net/10985/8612

\section{To cite this version :}

Wafa Samet KAFFEL, Yann LEDOUX, Jean-Pierre NADEAU - Eco-innovative Method to Improve the Distribution Phase of Product - 2013 


\section{Eco-innovative Method to Improve the Distribution Phase of Product}

\author{
Wafa Samet Kallel \\ Maître-Assistante: dept.Design \\ Institut Supérieur des Arts et Métiers de Sfax (ISAMS) \\ Sfax, Tunisie \\ wafa_samet@yahoo.fr
}

\author{
Yann Ledoux/Jean-Pierre NADEAU \\ Univ. Bordeaux, I2M, UMR 5295, F-33400 \\ Arts et Metiers ParisTech, I2M, UMR 5295, F-33400 \\ Talence, France
}

\begin{abstract}
The integration of the environmental dimension is crucial in industrial activity. Designers should integrate the new environmental constraints to adapt their approaches and methodologies in the framework of eco-innovation of industrial products and consumer goods. This paper proposes a new method integrating ecological aspects into the innovation process composed of three main stages: an analysis and structuring of the product, the formalization of the problem and the resolution phase. According to the structuring and the design objectives, actions can be selected and allow to guide the design to the most relevant modification to perform on the product. An illustration of the approach is applied on the optimization of the environmental impacts related to the logistical aspects.
\end{abstract}

Keywords- Triz theory, eco-innovation, sustainable development, distibution phase, actions for eco-innovation, functional and energy analysis, Eco-MAL'IN

\section{INTRODUCTION}

Due to ecological changes, the industrial companies have to modify their behaviors regarding product development. The objective is to make products all along with their lifecycles more environmentally friendly. Most industrial activities are responsible for the significant impact on our environment. Production in itself is not the only factor that is affecting our surroundings; the entire process, including distribution channels, upstream and downstream is also regarded as a major contributor to the deterioration of our atmosphere. We focus in this paper on the delivery phases of the product whether at the production level or the sales stage including all steps involved in warehousing, materials handling and transport. In this regard, the main question facing designers and engineers is "how can we innovate products and associated logistical aspects while respecting the environment? "

Until now, the logistics'innovations are mainly focused on economical aspects like cost reducing, infrastructure efficiency and optimization of the delivery time or the management of information flows,...However, these initiatives have never been thought since the design of the whole product. In this paper, we propose an original structuring to eco-innovate product called Eco-MAL'IN [1]. This method is mainly based on three steps guiding designer through innovation procedure by selecting most relevant actions to perform and leading to more efficient product facing to environmental constraints. All actions are related to the five main lifecycle steps (raw material extraction, production, use...). This methodology is particularly detailed on the distribution phase optimization. This approach allows to conclude on the necessity to commonly consider the innovation aspects of products and the logistical aspects.

\section{SUSTAINABLE DEVELOPMENT, INDUSTRIAL FRAMEWORK AND ECO-INNOVATION}

A general definition of the eco-innovation is proposed by the Organization for Economic Co-operation and Development (OECD). First, innovation consists to develop new or significantly improved products (goods or services), or process, a new marketing method, or a new organizational method in business practices, workplace organization or external relations [2]. Eco-innovation follows generally the same definition with two major distinctions: i) eco-innovation should represent innovation that results from a reduction of environmental impact; ii) the scope of eco-innovation may go beyond the conventional organizational boundaries of the innovating organization and involve broader social arrangements that trigger changes in existing socio-cultural norms and institutional structures $([3,4,5])$. To measure the scope of ecoinnovation approach is complex. Indeed, we must consider the basic constraints of any metric for eco-innovation assessment such as: the intergration of the three dimensions of sustainable development (social, economy, environmental), the external factors as temporality, the adaptability depending the different level of innovation and the ability of estimating the impact of eco-innovation approach before its implementation [6].

For companies, commit to a sustainable development policy is essential to reconcile economic development, environmental protection and social equity values. In this aim, several concepts, methods and tools have been developed. One of the main principles is to commonly consider eco-design aspects and innovation method in order to have a decisive advantage in international competition and thus ensure a sustainable future for the company.

\section{DATA TO INNOVATE INTO THE DISTRIBUTION PHASE}

\section{A. Eco-MAL'IN method}

Eco-MAL'IN corresponds to an eco-innovative method. From an initial product, the method is used to improve it into a new product considering the classical constraints so-called functional and technical constraints but also the environmental aspects. This method is composed of 5 steps as shown in figure 1. This figure details the steps and associated developed tools. 


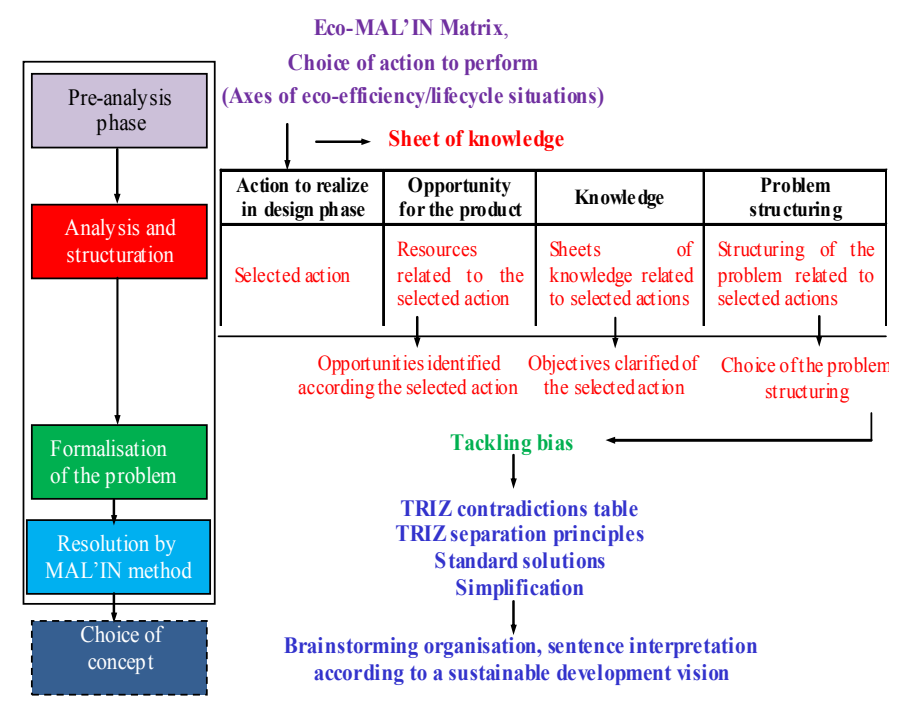

Figure 1. Synoptic of the methodology Eco-MAL'IN [7]

A pre-analysis phase: This phase defines a parsimonious analysis of the product and environmental aspects into a preliminary design phase. Based on the Eco-MAL'IN matrix, a set of action to perform is proposed. This phase allows to structuring and simplifies the analysis of environmental issues into eco-innovation. This point is usually difficult to determine by the engineers due to the complexity and the fuzziness of environmental impact of the future product while the product doesn't exist yet.

Analysis phase and structuring of the problem: The key parameters of the analysis phase in the proposed method are:

- The study of the whole product. This study concerns the analysis of components, interaction components and external environments of the product and the associated accessories. Materials, shapes and arrangements of components and interactions component are also analyzed.

- Functional flows. It identifies three types of flows: material, energy and signal. The functional flow analysis can focus on resource consumption or waste (loss of material, energy) caused by operating the product through relevant lifecycle situations. The characterization of these flows allows to identify solutions to their management.

- Analyzing and structuring tables related to systematic actions to perform. These tables include the actions to achieve the Eco-MAL'IN matrix, product opportunities, knowledge and guidance for structuring the problem. These key parameters of analysis are taken into account by the thirty-nine actions to realize that we have developed in the Eco-MAL'IN matrix .

Formalization phase: The Eco-MAL'IN formalization is based on priorities identified in the previous phase. It will lead to bias for eco-innovate the product defined below.

- Deleting or partial deleting of components
- Deleting or partial deleting of fields

- Segmentation of components

- Segmentation of fields

- Adjustment of spaces and changing layouts

- Selection of design parameters

- This bias will be used to select particular resolution tools.

Solving phase and concept selection: The resolution method uses in Eco-MAL'IN is derived from TRIZ tools [8] or those adapted by the MAL'IN method. We distinguish different resolution tools:

- The tool "resources" to generate ideas for innovative solutions in relation to these resources throughout the product.

- The matrix of technical contradictions (TRIZ) [9] or separations matrix of conflicting requirements from MAL'IN.

- The flowchart choice of standard solutions.

- The simplification and elimination of substances.

\section{B. The pre-analysis: a structured vision of environmental impacts of product}

The pre-defined phase defined a simplified and structured environmental issues by the means of the Eco-MAL'IN matrix [1]. It is an integrated approach to eco-efficiency areas and relevant situations of the lifecycle of the product (Table 1). This matrix offers several goals that environmental design can act on an axis of eco-efficiency or improve a particular lifecycle stage of product. Considered the lifecycle stage "distribution" of product is relevant according to the EcoMAL'IN matrix. The "distribution" takes into account all the different transport and logistics phases which associated to the product. And more particularly, the steps involved in the storage, handling and delivery of the finished product to the end customer.

TABLE I. RELATION BETWEEN THE LIFECYCLE PHASES AND THE AXES OF ECO-EFFICIENCY.

\begin{tabular}{|c|c|c|c|c|c|}
\cline { 2 - 6 } \multicolumn{1}{c|}{} & $\begin{array}{c}\text { Raw } \\
\text { extraction } \\
\text { material }\end{array}$ & Manufacturing & Distribution & Use & $\begin{array}{c}\text { End } \\
\text { of } \\
\text { life }\end{array}$ \\
\hline $\begin{array}{c}\text { A. Reducing } \\
\text { the material } \\
\text { influence }\end{array}$ & $\times$ & $\times$ & $\times$ & $\times$ & $\times$ \\
\hline $\begin{array}{c}\text { B. Increasing } \\
\text { the energy } \\
\text { efficiency }\end{array}$ & & $\times$ & $\times$ & $\times$ & $\times$ \\
\hline $\begin{array}{c}\text { C. Reducing } \\
\text { the toxicity } \\
\text { risk }\end{array}$ & & & & & $\times$ \\
\hline $\begin{array}{c}\text { D. Increasing } \\
\text { the } \\
\text { recyclability } \\
\text { and the reuse }\end{array}$ & & & & $\times$ & $\times$ \\
\hline E. & & & & $\times$ & $\times$ \\
\hline
\end{tabular}




\begin{tabular}{|c|l|l|l|l|l|}
\hline $\begin{array}{c}\text { Optimizing } \\
\text { resource } \\
\text { utilization }\end{array}$ & & & & & \\
\hline $\begin{array}{c}\text { F. Increasing } \\
\text { the } \\
\text { durability } \\
\text { and the } \\
\text { desirability } \\
\text { of the } \\
\text { product. }\end{array}$ & & & & $\times$ & \\
\hline $\begin{array}{c}\text { G. Increasing } \\
\text { the } \\
\text { functionality } \\
\text { and the } \\
\text { services. }\end{array}$ & & & $\times$ & $\times$ & \\
\hline
\end{tabular}

By the intersection of the axes of eco-efficiency ([10,11]) and the relevant lifecycle situations, we defined actions to guide designers towards environmental design of an existing product. This approach is not a global analysis of all existing environmental problems, but it's a selective approach which is based on the identification of the most relevant parameters related to a specific problem $([12,13,14,15])$. The designer has to define priorities, choosing to act on one or more axes of eco-efficiency (environmental impacts) or focus its actions on a particular lifecycle situation. Developed actions allow take into account the component of product, interaction components and surrounding element of the product (environment) [16], [17]. Before explaining in detail the actions associated with the distribution phase, we define the whole product. This section will present an overview of the product and the workflow of consumption and waste which are associated with the product lifecycle.

\section{The whole product definition}

The industrial product should not be considered as an isolated entity, but like a whole product formed by the product itself and its accessories products. The product is composed by a set of components, components for interaction and external environments [1].

- The components perform both the functions of services and functions of constraints defined by the functional requirement specifications.

- The components of interactions are used to link the components together, to connect the components to a reference and also to ensure the required functional flows.

- The external environments affect the environment of the product. This can be fluid material, coming from energy supplier, corresponds to the user, to the environment.

Accessory Products can be protective packaging used for the transportation, the sale, the promotion, the marketing, the information vector, the normative or regulatory documents, the instruction manual, advertising documents, delivery documents, software support accompanying the product. As a product, an accessory product contains components, components of interaction and external environments. It provides specific functions related to function of constraints linked to the evolution of the product throughout its
lifecycle.The evolution of a product involves all interactions with external environments and the impacts of every lifecycle situation by the consumption of resources and generation of waste. These releases can be components or parts of components (consumables / non-consumables), fluid operation, effluents, noise or the whole product in some cases. Improving the design of the whole product therefore allows on one hand to reduce the consumption of resources and, on second hand, to remove, the process and minimize generated waste in every lifecycle phases. Figure 2 shows the relationship between the product and all generated waste.

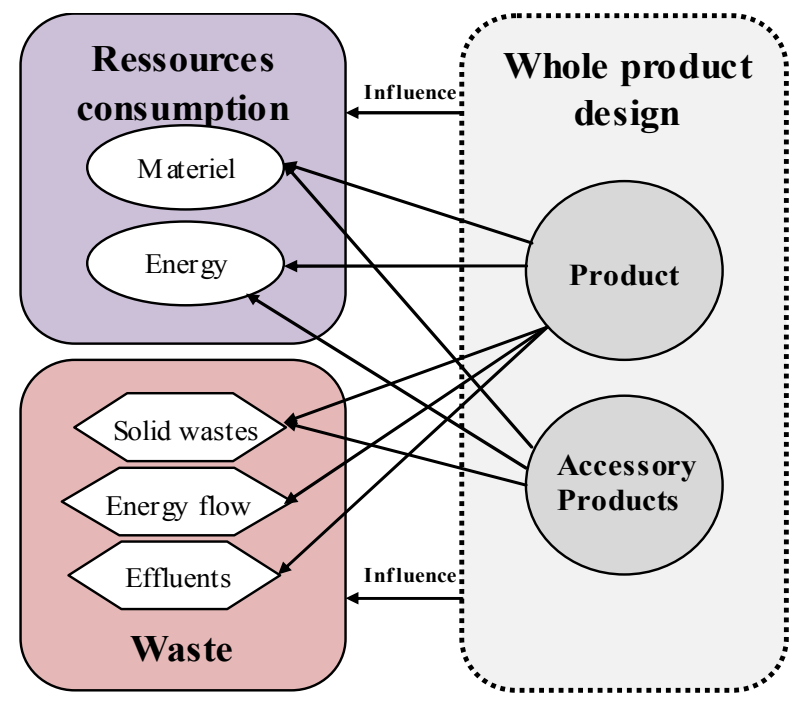

Figure 2. Relations between release and the whole product.

Accessory products become waste of the whole product when they successfully completed their functions. This can be packaging, media information, software support, energy flows and effluents. Discharges from accessory products can be associated with the distribution or use phase of the product lifecycle situations.

\section{The pre-analysis phase and action to perform}

In this paper, we deal with the distribution phase and actions to achieve. Each action will directly or indirectly influence the use of material resources and energy (Table 1).

Associated with the axis A) Reduce material influence, the first action, "Optimize the whole products to minimize emissions during distribution phase" refers to the evolution of the whole product in order to act on releases and consumables during the distribution phase. The integration of this action should lead to control the release of the whole product such as solid waste and avoid consumables packaging (temperature, pressure, humidity) when it will be transported and distributed.

Associated with the $\mathrm{C}$ axis) Release the risk of toxicity, the second action "Allow stability or controllability of the flow of materials and energy and their toxic interference" refers to the possibility of loss of materials or rejection of toxic energies or material during the distribution phase. The design of the whole product should consider this possibility. In such case, the designers have to ensure that this point stay under control whatever the situation of the product lifecycle. 
Associated with the axis G) Increase the functionality and services, the last action, "Integrate to the whole product functions to improve the distribution phase" will involve changes in the design of the whole product in order to improve the phase distribution. This action is necessary to transform functions in distribution phase to a part or the whole product such as their combinations and stacking when is necessary for the handling or storage during the transport phase. The objective of this action is to rethink both the design of the whole product and associated functions to optimize the distribution. The goal is to migrate some of these functions across product.

These different actions should lead to innovation on the whole product. These actions can be used in brainstorming phase with a group of creativity.

\section{INNOVATIVE THE DISTRIBUTION PHASE}

We defined tables aiming at analyzing and structuring the design problem according to the selection of particular action to perform. Table 2 summarizes the analytical approach proposed for these actions.

Opportunities are specific to every selected action and are defined from a resource list available in Eco-MAL'IN. Adapted to a sustainable development vision, this list is an improvement from environmental point of view of the previous development of Savransky [8]. Annex 2 presents an analytical framework for each resource in terms of sustainable development [1]. The analysis of the whole product is then conducted through the study of knowledge sheets and every action to perform.

TABLE II. ACTION ASSOCIETED WITH THE PHASE OF DISTRIBUTION

\begin{tabular}{|c|c|c|c|c|}
\hline $\begin{array}{l}\text { Lifecycle } \\
\text { situation }\end{array}$ & $\begin{array}{c}\text { Action to } \\
\text { realize in } \\
\text { design } \\
\text { phase }\end{array}$ & $\begin{array}{l}\text { Opportuni } \\
\text { ty for the } \\
\text { product }\end{array}$ & Knowledge & $\begin{array}{c}\text { Problem } \\
\text { structuring }\end{array}$ \\
\hline \multirow{3}{*}{ Distribution } & $\begin{array}{l}\text { 1. Optimize the } \\
\text { whole } \\
\text { product to } \\
\text { minimize } \\
\text { wastes } \\
\text { during } \\
\text { distribution } \\
\text { phase }\end{array}$ & $\begin{array}{l}\text { Substances, } \\
\text { time, waste }\end{array}$ & $\begin{array}{l}\text { Data sheet } \\
\text { listing the } \\
\text { wastes and } \\
\text { consumables } \\
\text { required by } \\
\text { the whole } \\
\text { product in } \\
\text { the } \\
\text { distribution } \\
\text { phase }\end{array}$ & $\begin{array}{l}\text { Segmentation } \\
\text { fields } \\
\text { Space } \\
\text { adjustment and } \\
\text { modification of } \\
\text { the } \\
\text { arrangements }\end{array}$ \\
\hline & $\begin{array}{l}\text { 2.Allow the } \\
\text { stability and } \\
\text { controllabilit } \\
\text { y of } \\
\text { materials } \\
\text { and energy } \\
\text { flow and } \\
\text { their toxic } \\
\text { interference }\end{array}$ & $\begin{array}{l}\text { Interaction } \\
\text { resources, } \\
\text { organizationa } \\
1 \text { resources, } \\
\text { differential } \\
\text { resource }\end{array}$ & $\begin{array}{l}\text { Data sheet } \\
\text { listing the } \\
\text { risk of } \\
\text { toxicity in } \\
\text { the phase of } \\
\text { distribution }\end{array}$ & $\begin{array}{l}\text { Total or partial } \\
\text { suppression of } \\
\text { fields } \\
\text { Segmentation } \\
\text { fields } \\
\text { Selection of } \\
\text { relevant } \\
\text { parameters } \\
\text { (constraint, } \\
\text { pressure, } \\
\text { temperature } \\
\text { stability of the } \\
\text { entity) }\end{array}$ \\
\hline & $\begin{array}{l}\text { 3.Integrate to } \\
\text { the whole } \\
\text { product } \\
\text { functions } \\
\text { improving } \\
\text { the phase } \\
\text { distribution }\end{array}$ & $\begin{array}{l}\text { Substances, } \\
\text { energy, } \\
\text { space, time, } \\
\text { self-service, } \\
\text { differential } \\
\text { resource }\end{array}$ & $\begin{array}{l}\text { Qualification } \\
\text { of the whole } \\
\text { product } \\
\text { resources in a } \\
\text { vision of } \\
\text { increasing } \\
\text { function }\end{array}$ & $\begin{array}{l}\text { Segmentation } \\
\text { fields } \\
\text { Space } \\
\text { adjustment and } \\
\text { modification of } \\
\text { the } \\
\text { arrangements }\end{array}$ \\
\hline
\end{tabular}

In this section, we show how from an action to perform, we can bring innovative ideas for the distribution phase. By the action "Optimize the whole product to minimize releases during distribution phase" it is necessary to redesign the whole product to limit the use of accessory products related to handling, protection or transport phase to finally eliminate the accessory product. By reducing the volume of the whole product, storage and transport will be better managed and therefore emissions such as energy flow or effluent during transport will be minimized. By this turn, that leads to a more compact design, to optimize the arrangements of components and then minimize the needed energy for distribution.

In addition, if it is considered the substance resource available as a first item of the Annex 2, then, the whole product, components or components of interaction of the external environment like consumable or release should be qualified. The substances can be considered as loseable components with no particular functionality, redundant,... or non-reusable components and thus, as a component which has to be suppressed or to be change to make them reusable (Annex 2). Thus, any entity of the whole product provide only specific functions constraints as the accessory products, linked to the evolution of the product throughout its life cycle, will think for elimination. The second resource of this table corresponds to time. This is a relevant opportunity since this action can be partially or entirely reduced the release and waste during distribution phase by adopting for example, the concept of the logistic mutualization. Finally, emissions could become resources to perform the distribution. Emissions generated during this phase must be analyzed in a recovery, elimination or evolution of the emissions of the system open to the closed circuit. The Knowledge sheets template associated with this action is not presented in the paper. However, their content corresponds to a list of releases and consumables products. We speak of solid waste, and energy flows of effluents related to packaging requirements at this lifecycle phase. Once the creativity group has identified opportunities related to the product and relevant knowledge sheets, it must rethink the whole product to respect all the required functions. To do this, we should at the beginning define a functional model from the opportunities offered by the methodology MAL'IN.

- By writing the physical model and realize an energy analysis [16].

- By using the substance-fields analysis and associated graph [18].

Then, we can express patterns of problems by TRIZ theory through analysis of graph [18], by identification of relevant parameters in physical models [16] or by definition of technical or physical contradictions. The problem is solved by the mean of tools developed in TRIZ theory through brainstorming activity. From one model selected, we can choice the problem structuring. For the action "Optimize the whole product to minimize releases during distribution phase", two structuring of the problem have been proposed (Table 2):

In the first case, the segmentation of functional fields will introduce new interactions into the whole product and will add new fields to the substance / field graph reflecting the 
functioning of the system. The action: "Minimize releases during the distribution", will introduce fields that avoid or eliminate consumables packaging such as controlled environments, or keep safe specific fluids during transport. These relevant fields can still generate unintended consequences and may affect the functioning of the product. It is then propose to use MAL'IN software to solve problems and resulting contradictions.

In the second case, the adjustment of spaces and changing layouts also induces fields in some cases may have antagonist effects. The treatment of these effects requires like in the first case, the use of the MAL'IN models to express and then to solve problems and contradictions.

\section{CONCLUSION}

We propose in this paper a method for integrating constraints for sustainable development in the phases of research of innovative concepts. This method is based on functional analysis, on a thorough analysis of the whole product, on energy analysis of physical behavior and solving tools derived from TRIZ theory. In this method, we define a pre-analysis phase based on the simplified evaluation matrix of lifecycle situation and the seven axes of eco-efficiency defined by WBCSD. This Eco-MAL'IN matrix defines a set of actions to guide designers in the preliminary stages of design to act on one or more axes of eco-efficiency or focus its actions on a particular lifecycle situation (extraction of raw materials, industrialization, distribution, use and end of life).

In the first part, we explained the relevance of the matrix particularly the actions related to the distribution phase. It was also shown the relevance of the functional approach defined by this matrix for structuring the design problem that suggests jointly the design of the whole product and its distribution, including all steps involved in warehousing, materials handling and transportation. Secondly, we illustrated a particular action: "Optimize the whole product to minimize releases during the distribution phase", from the analysis phase, the problem structuring to the definition of tackling bias. To establish this methodology, we relied on the analysis of opportunities, knowledge sheets to determine a particular structuring of the problem allowing use tools existing in the methodology of Eco-MAL'IN. By this approach, we presented different solutions to minimize releases during distribution phase such as: reducing the accessory products, act on packing requirements and interactions with the external environment to reduce supplies and discharges during the distribution phase). This approach to eco-innovation has enabled to identify structure and formalize a design problem on the whole product in preliminary design phase and then to bring innovative ideas to its distribution phase.

The analysis of the opportunities of a product or a service in order to allow their evolution can also lead to innovate the distribution phase. We develop a method based on research opportunities for development of products and services from the analysis of existing systems and patents. This method relies on the analysis of physical phenomena, the laws of evolution of technical systems and actions to perform in order to reduce the environmental impacts shown in the text. The first work of application concerns the transport oil.

\section{REFERENCES}

[1] W.Samet kallel, "Développement d'une methode d'éco-innovation: EcoMAL'IN," thèse de doctorat, Arts et métiers ParisTech, Centre Bordeaux, 2010.

[2] OECD, 2005, Oslo Manual: Guidelines for Collecting and Interpreting Innovation Data, third ed. OECD, Paris.

[3] OECD, 2009, Sustainable manufacturing and eco-innovation. Framewok, practices and measurement. Synthesis report. Paris. Available at: www.oecd.org/sti/ innovation/sustainablemanufacturing

[4] OECD, 2009, Sustainable manufacturing and eco-innovation: towards a green economy. Policy Brief June 2009.

[5] C.M, Beard and R. Hartmann, "Eco-innovation: Rethinking Future Business Products and Services," (chapter in Book) In: Greener Marketing, by Charter, M \& Polonsky, J , Greenleaf Publishing, Sheffield, 1999.

[6] Scarpellini S, et al., "Multicriteria analysis for the assessment of energy innovations in the transport sector", Energy (2013), http://dx.doi.org/10.1016/j.energy.2012.12.004

[7] MAL'IN, web site: http://www.trefle.u-bordeaux1.fr/malin/

[8] S.D. Savransky, "Engineering of creativity, Introduction to TRIZ methodology of inventive problem solving," CRC Press, Boca Raton, Florida, 2000.

[9] G.S. Altshuller, "TRIZ, The innovation algorithm systematic innovation and technical creativity," Technical Innovation Center Inc., Worcester, 1999.

[10] A. Sturm, K. Müller and S. Upasena, "A manual for the preparers and users of eco-efficiency indicators," 2004.

[11] World Business Council for Sustainable Development, "Eco-Efficiency Indicators: A tool for better Decision-Making," Technical Report, 1999.

[12] Afnor, FD X30-310, "Management environnemental: prise en compte de l'environnement dans la conception et le développement des produitsPrincipes généraux et application -Ligne directrices", 1998, pp1-16.

[13] H. Brezet and C. Van Hemel, "Eco-design: A promising approach to sustainable production and consumption," Rathenau Institute, TU Delft \& UNEP, Paris, 1997.

[14] H. Kobayashi, "A systematic approach to eco-innovative product design based on life cycle planning," Advanced engineering informatics, 2006, Vol. 20, pp. 113-125.

[15] D. Millet, "Intégration de l'environnement en conception : l'entreprise et le développement durable," Lavoisier, ISBN 2-7462-0732-X, chapitre $\mathrm{N}^{\circ} 1$, Paris, 2003.

[16] J. Pailhes, M. Sallaou and JP. Nadeau, "Knowledge base formulation for aided design tool", Trends and Recent Advances in Integrated Design and Manufacturing in Mechanical Engineering II, 2007, pp 231-243, Springer Verlag.

[17] W. Samet, Y. Ledoux and J.P. Nadeau, "Eco-innovation tool for Mal'in software, illustration on a waffle iron", Proceedings of IDMME - Virtual Concept 2010, Bordeaux, France, October 20 - 22, 2010.

[18] B. Zlotin, "Tools of Classical TRIZ", ISBN 1-928747-02-7, Ideation International Inc, 1997. 


\section{Annex 2: analytical framework for sustainable development}

\section{1) Substances}

Number of components

Components loseable, not functional, redundant, disposable, toxic, fragmentalble, not reusable.

External environments (consumables)
2) Energy
Open circuit
Closed circuit accumulation
Renewable energy and clean
Non toxic energy

\section{3) Information}

Material identification, appearance, material colour

Material sustainable, biodegradable, renewable, recyclable, recoverable, resilient, non-energy intensive, non-corrosive, non toxic

Types of manufacturing, raw components

Durability, longevity of components

Waste: smell, hearing, sight, colour, aggression, warmth...

4) Space

Using space to increase the capacity of the system or to regenerate materials or energy.

5) Time

Use the time to increase the capacity of the system or to regenerate materials or energy.

6) Functional resources

Analysis of these functions in the vision of sustainable development.

7) Self-service

Generation of wastes or loss of energy,

Buoyancy (material and form) for recycling

Density of fluids for recycling

Thermo-plasticity for recycling

Fluid retention (porosity, permeability...)

Miscible blends, non-miscibility.

Opacity and Transparency (containment components)

Reusability.

8) Resources of interactions

Standardization of the components of interaction

Poly-material components to multi-component materials and separable components,

Separable component,

From static to dynamic for better control and increased efficiency,

Improved loss by controlling interactions, Free passage of energy.

\section{9) Organizational resources}

Optimization of resources, compactness,

Control and reduction of energy flow, material and signal

Containment System (security, self-sufficiency, safety)

Modularity system for recycling

\section{0) Differential resources}

Control and reduction of energy flow, material and signal

11) Anterior resources

Disposal of surplus material, components

Control and reduction of energy flow, material and signal

12) Waste

Recovery and suppression of waste

Modification from open circuit to closed circuit. 